\title{
The Halifax Explosion of 1917: the oculist experience
}

Chryssa N. McAlister, ${ }^{*}$ MD; T. Jock Murray, ${ }^{\dagger}$ MD, FRCPC; Charles E. Maxner, ${ }^{\dagger \ddagger}$ MD, FRCPC

\section{ABSTRACT•RÉSUMÉ}

Background: Despite its prominence in Canadian history, there are few publications about the Halifax Explosion of 1917 that deal with the care of victims with eye injuries.

Methods: Archived documents relating to the nature and treatment of eye injuries sustained during the Halifax Explosion were reviewed at the Public Archives of Nova Scotia and the Maritime Museum of the Atlantic. A review of current literature was performed.

Results: Detailed accounts regarding the personal and surgical experience of 2 ophthalmologists, G.H. Cox and F.T. Tooke, were found. Several unpublished government and personal documents on eye injuries sustained during the Halifax Explosion are filed at the Public Archives of Nova Scotia. Twelve ophthalmologists treated 592 people with eye injuries and performed 249 enucleations. Sixteen people had double enucleations. Most of the eye injuries were caused by shards of shattered glass. Sympathetic ophthalmia was the feared complication for penetrating eye injuries and a common indication for enucleation in 1917. A Blind Relief Fund was established to help treat, rehabilitate, and compensate the visually impaired.

Interpretation: Many of the eye injuries sustained during the Halifax Explosion were due to flying shards of glass. Details of their treatment provide insight into a unique and devastating event in Canadian medical history and demonstrate how eye injuries were managed in 1917.

Contexte : Malgré toute l'importance qu'a eue dans l'histoire canadienne l'explosion d'Halifax en 1917, peu de publications ont fait état des soins qui furent alors prodigués aux personnes qui avaient subi des blessures aux yeux.

Méthodes : Les documents d'archive relatant la nature et le traitement des blessures oculaires subies lors de l'explosion d'Halifax ont été réexaminés aux Archives publiques de la Nouvelle-Écosse et au Musée maritime de l'Atlantique. L'on a aussi examiné la littérature actuelle.

Résultats : L'on a trouvé des comptes rendus détaillés de l'expérience personnelle et chirurgicale de 2 ophtalmologistes, G.H. Cox et F.T. Tooke. Les archives publiques de la Nouvelle-Écosse comprennent plusieurs documents gouvernementaux et personnels non publiés sur les blessures subies lors de l'explosion d'Halifax. Douze ophtalmologistes ont soigné 592 personnes pour blessures oculaires et effectué 249 énucléations. Seize personnes ont subi une double énucléation. La plupart des blessures oculaires furent causées pas des tessons de verre. L'on a craint alors la complication d'une ophtalmie sympathique à cause de la blessure oculaire pénétrante, ce qui en a fait une indication d'énucléation répandue en 1917. Un Fonds de secours pour les aveugles a été créé pour aider au traitement, à la réadaptation et à l'indemnisation des personnes victimes d'une déficience visuelle.

Interprétation : Beaucoup de blessures subies lors de l'explosion d'Halifax furent attribuables aux tessons de verre volants. Les détails des traitements donnent un aperçu de cet catastrophe unique et dévastatrice de l'histoire médicale canadienne et fait voir comment l'on prenait en charge les blessures oculaires en 1917.

$I^{n}$ n 1917, Halifax, a city of 47000 , was heavily involved in the First World War and was therefore vulnerable as a primary target should the Germans attack the Eastern seaboard. ${ }^{1}$ On December 6 of that year, at 9:05 AM, the Mont Blanc, a French freighter, exploded in Halifax harbour, destroying everything within a $2.5 \mathrm{~km}$ radius and shattering windows across the city (Fig. 1). ${ }^{2}$ Soon to be

From *the Department of Ophthalmology \& Vision Sciences, University of Toronto, Toronto, Ont.; and ${ }^{\dagger}$ the Department of Medicine (Neurology) and ${ }^{\ddagger}$ the Department of Ophthalmology \& Visual Sciences, Dalhousie University, Halifax, N.S.

Originally received Oct. 30, 2007. Revised Nov. 29, 2007

Accepted for publication Dec. 13, 2007

Published online Jan. 22, 2008 labeled "the Halifax Disaster" by the media, many initially suspected the Germans were responsible for the explosion. ${ }^{3}$ It later transpired that a navigational error in Halifax harbour between two ships, the Imo, a Belgian relief ship, and the Mont Blanc, caused the collision. ${ }^{2}$ The Mont Blanc carried several tons of explosives, including picric acid, trinitrotoluene, benzol, and gun cotton. The impact caused

Correspondence to: Chryssa N. McAlister, MD, University of Toronto, Department of Ophthalmology \& Vision Sciences, TWH, Room 7E-401 \& 403, 399 Bathurst Street, Toronto, ON M5T 2S8; chryssa.mcalister@utoronto.ca

This article has been peer reviewed. Cet article a été évalué pars les pairs.

Can J Ophthalmol 2008;43:27-32 doi:10:3129/i07-218 
the benzol to ignite and form a column of smoke, which rose 2000 feet into the air. The people of Halifax went to their windows to watch. Seventeen minutes later, the Mont Blanc exploded. Extensive literature exists on the historical and medical details of the Halifax Explosion. Many make reference to the staggering number of eye injuries sustained during the explosion. However, little detail is provided about the nature of the eye injuries and the ophthalmologists involved in their treatment.

\section{Methods}

All relevant written documents and photographs at the Public Archives of Nova Scotia and the Maritime Museum of the Atlantic relating to the Halifax Explosion were searched and reviewed. A search of the PubMed database was performed to locate literature suitable for inclusion. A search of historical literature was performed through the Dalhousie University libraries and the Halifax public libraries. Reference lists from included publications were also checked for potentially relevant articles. Detailed search strategies are available from the authors.

\section{Results}

Several published and unpublished documents on the medical aspects of the Halifax Explosion were found, including scientific articles, letters, telegrams, government documents, newspaper clippings, and historical books. Several archived photographs were found, and one undated photograph of an unknown ophthalmologist examining a child was found through the Dalhousie University libraries in a file marked "Halifax Explosion" (Fig. 2).

A military ophthalmologist, F.T. Tooke, published an article in the Canadian Medical Association Journal in 1918, entitled, "An experience through the Halifax Disaster." ${ }^{4}$ An unpublished, undated, hand-written speech was found in G.H. Cox's files at the Public Archives of Nova Scotia, in which he describes his personal experience in the Halifax Explosion. ${ }^{5}$

Several original telegrams were found, including one from the governor of Massachusetts, S. McCall, dated December 6, 1917, offering assistance in any form to the city of Halifax. ${ }^{6}$ Telegrams from the Halifax Relief

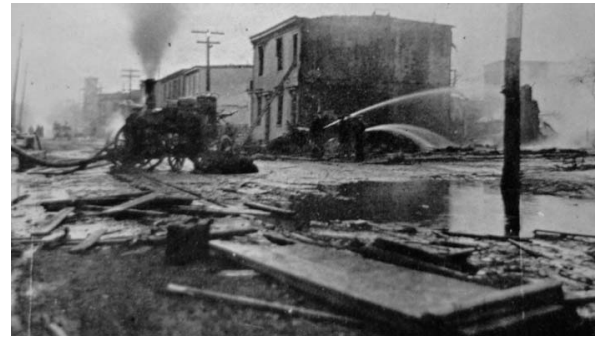

Fig. I-An archival photograph of Gottingen Street in Halifax after the Halifax Explosion in December 1917.
Committee detail the city's needs, and the progress and services provided for medical relief. ${ }^{7}$

A Medical Relief Committee document, published in January 1918, describes the medical injuries from the Halifax Explosion and the treatments provided, including 56 blind cases, 206 enucleated cases, and 260 "doubtful as yet" cases where prognosis for vision was guarded. A total of 522 eye cases were reviewed, with 144 eye cases still incomplete. At that time, 21 artificial eyes and 245 eyeglasses were supplied to those with eye injuries, the costs covered by the Medical Relief Committee. ${ }^{8}$

Among the numerous articles on the Halifax Explosion is a newspaper clipping from Sir Frederick Fraser, superintendent of the Halifax School for the Blind (est. 1871), dated January 1918, requesting information from persons who sustained eye injuries in the Explosion.?

The Halifax Relief Committee documents include a list of the number of children blinded according to age, along with a number of unpublished, hand-written letters. These letters were written by patients with eye injuries, or by the parents of children with eye injuries, to Sir Frederick Fraser in response to his newspaper request. Many describe the mechanism of their injury, their age and sex, the treatment they received, and the hospital and ophthalmologist involved in their care (Fig. 3). Listed ophthalmologists include —— Donell, A.E. Doull, D. Harvey, —— Keddy, E.A. Kirkpatrick, — MacIntosh, R.E. Mathers, McLennan, — Miller, S.A. Sutton, A.L. Williamson, and - Woods. No letters were found with the names G.H. Cox or F.T. Tooke as the listed surgeon. ${ }^{7}$

An unpublished document entitled, "Fraser Harris Report: The medical relief work of the Halifax Disaster" was found. ${ }^{10,11}$ Under the subheading, "Injuries to the Eyes," a detailed account of the medical management of eye injuries makes reference to the following oculists: A.R. Cunningham, A.E. Doull, E.A. Kirkpatrick, and R.E. Mathers of Halifax; G.H. Cox of New Glasgow; F.T. Tooke of Montreal; and D. Harvey and J.W. Stirling of Boston.

Included in this document is a list by name and address of patients who received double enucleations; a letter

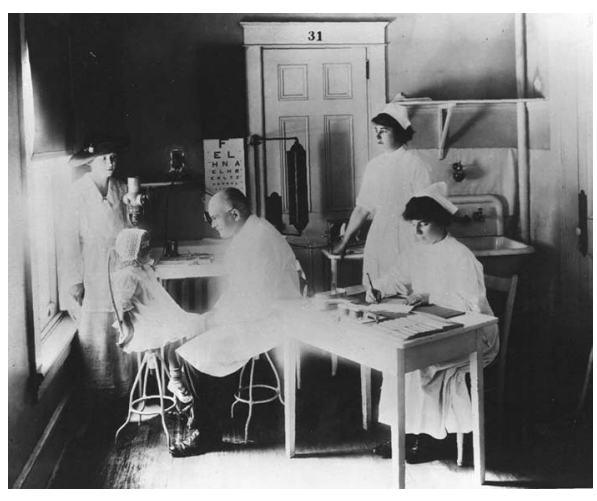

Fig. 2-Undated photograph of an unknown ophthalmologist examining a child, found in the Halifax Explosion archives at Dalhousie University. 
written by R.E. Mathers of his experience; and a list of the artificial eyes and eyeglasses supplied to those with eye injuries. In his letter, Mathers acknowledges the assistance of two Boston ophthalmologists: R. MacKenzie and Goodall. ${ }^{10}$ No other references to the aforementioned ophthalmologists were found. Documents filed under the Massachusetts-Halifax Relief Committee include several reports on the state of public health in Halifax, including the need for aid to the blind. ${ }^{12}$

Four published books on the Halifax Explosion provide details on the medical response, and make reference to several of the above documents. ${ }^{3,11,13,14}$ In a recent article, we reviewed the eye injuries suffered during the Halifax Explosion. ${ }^{15}$ No other articles were found on this topic.

In the days following the Halifax Explosion, 12 oculists treated 592 patients with eye injuries. They performed a total of 249 enucleations and 16 double enucleations. ${ }^{10}$ The overall enucleation rate for all 12 ophthalmologists was $48 \%$.

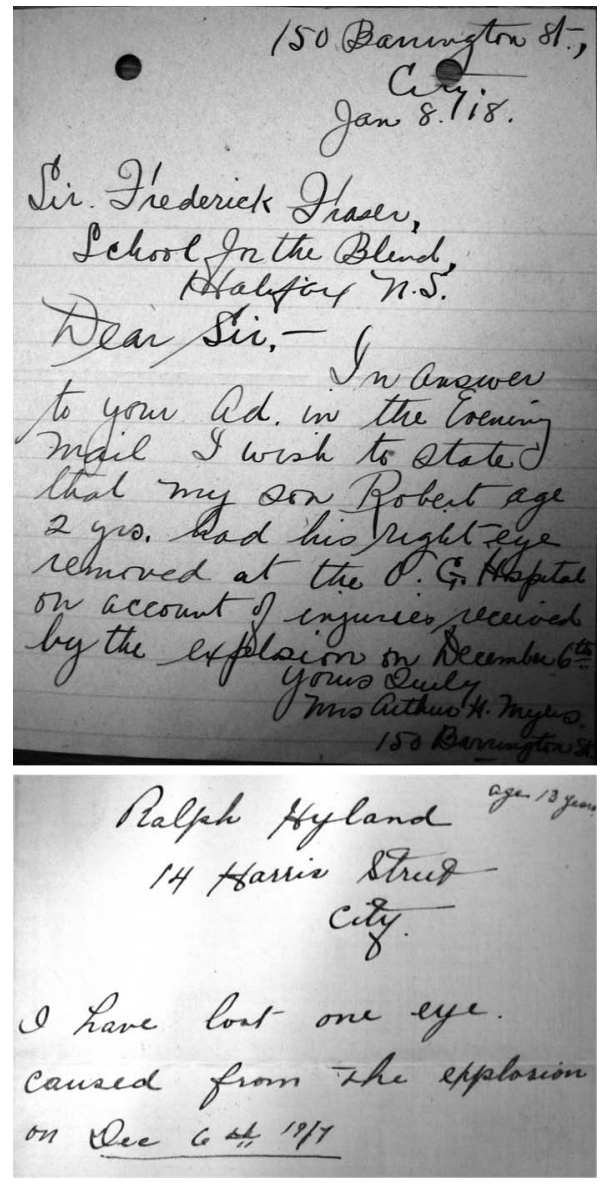

Fig. 3-Examples of letters archived by the Halifax Relief Committee documenting eye injuries sustained by victims of the Halifax Explosion. A January 1918 letter written by Mrs. Arthur H. Myles describing the removal of her 2year-old son's right eye at the O.G. Hospital in Halifax (top). A letter from 13-year-old Ralph Hyland stating the removal of one eye following the explosion (bottom).
The medical response to the Halifax Explosion involved 322 physicians, including 52 from the Halifax area. ${ }^{8,11}$ One hundred and twenty physicians came from the United States and more than 100 came from Canadian provinces. ${ }^{10,11}$ Recent data suggest that 9000 people were injured in the explosion and nearly 2000 died (Fig. 4). ${ }^{16}$

\section{INTERPRETATION}

On December 8, 1917, Captain F.T. Tooke, an ophthalmologist from Montreal, reported to duty. A telegram was sent from Halifax regarding an unusual number of eye casualties sustained 2 days before in an explosion. With a complete set of surgical eye instruments, Tooke boarded a train that would be delayed in blizzards and snowdrifts. He arrived in Halifax on the morning of December 10 to find the city destroyed. ${ }^{4}$

"The day was dark and cold and the details of the city could scarcely be made out," said Tooke. "The roof of the Canadian Government Railway Station had fallen in ... and we were compelled to make our way through a sea of broken glass and over countless obstacles, chiefly wreckage and coffins," he added. "The silence was intolerable and Halifax at first impression seemed to be in fact a city of the dead" (Fig. 5). ${ }^{4}$

Tooke was assigned to the Camp Hill Military Hospital where he met local ophthalmologists who had been operating for 4 straight days. "I was taken to a small back room lighted by a single electric globe," Tooke recollected. 4 "Here a man was operating who was introduced to me as Dr. Cox of New Glasgow.... Most of the night he had been working

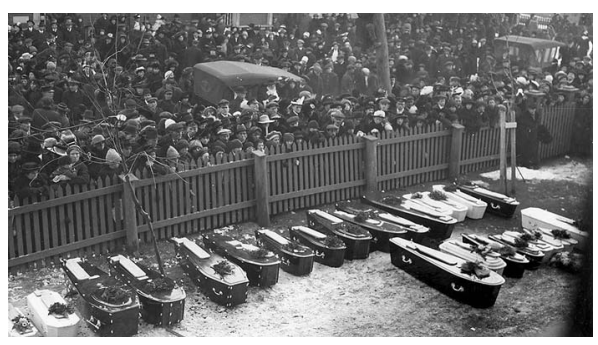

Fig. 4-City of Toronto archival photograph showing a funeral for victims of the 1917 Halifax Explosion.

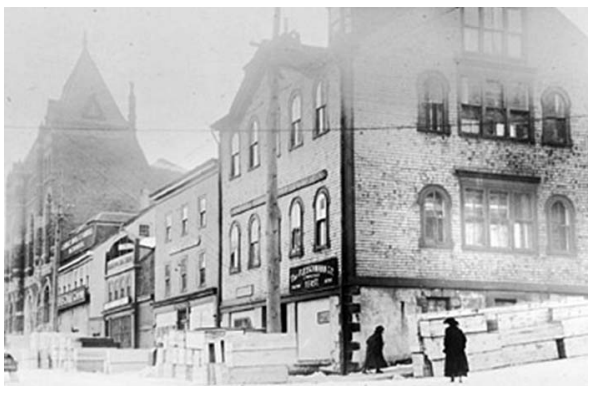

Fig. 5-Archival photograph of a Halifax street corner lined with coffins following the explosion in 1917. 
in the kitchen and operating on the floor." Tooke said Cox looked as if he had aged 20 years from the fatigue. "He was manifestly exhausted," said Tooke, "and he told me that he had done so much work that his instruments would no longer cut." ${ }^{\prime \prime}$

Four days before, on the morning of the explosion, Dr. George Cox heard of the disaster by telegram. ${ }^{5}$ In his town of New Glasgow, $160 \mathrm{~km}$ away, dishes had rattled. However, Cox knew nothing of the staggering number of eye injuries he would encounter. A relief expedition of 11 doctors and nurses was quickly organized and they arrived by train at 5 PM on December 6 to find a horrific scene. "We had to make our way along streets and tracks blocked and covered with debris of all sorts ... and every here and there dead men on piles of black stuff, corpses already gathered by the scavengers," remembered Cox. ${ }^{5}$

Cox walked to the Camp Hill Military Hospital, a new facility of 250 beds, to find 1500 injured men, women, and children lining the beds, hallways, and floors. ${ }^{5}$ Physicians involved in the medical response worked out of the 8 established local hospitals and several temporary hospitals. The Medical Relief Committee, established on December 8, 1917, set up temporary hospitals around the city in private offices, schools, clubs, and homes, to treat the injured. A total of 57 temporary hospitals and dressing stations were registered (Fig. 6). ${ }^{17}$

Cox first responded by attending to general needs, repairing wounds, and setting broken bones, until he realized that his services as an oculist would be needed. Cox operated on injured eyes for 5 straight days. "I have no records to show the nature and number of cases treated," he recollected, "but I know that some days averaged one chloroform case every 15 minutes, while I was often able to sandwich in a cocaine case while my next patient was going under." 5

Most eye injuries resulted from flying glass, since many people stood at their windows watching the burning Mont Blanc before the explosion. ${ }^{10}$ Cox found imbedded pieces of glass as large as 1 inch square. "Pieces of glass were driven clear thro' the eyeball," said Cox, "and one found it was necessary to feel about in the orbital tissue before dressing the case." 5

With the help of an orderly, a nursing sister, and an anesthetist, Cox performed 75 enucleations and 5 double enucleations, all under chloroform anesthesia. Cox would find the sclerotic attachments for the muscles, cut the tendons and the optic nerve, and remove everything under Tenon's capsule. ${ }^{5}$

"In addition of course to the enucleated cases," Cox recounted, "- -and in them there was seldom any doubt to its advisability, so utter was the destruction-there were large numbers of cuts to the cornea of various lengths, with prolapse of the iris in most cases." Many of the cornea cases were performed under cocaine anesthesia, cutting prolapsed iris or ciliary body, replacing edges of iris, and putting in necessary sutures.

Cox also operated on lacerated lids. "Eyelids were cut into literal fringes," he said, "and in addition to removal of the "ball one often had to hunt to find material to reconstruct a set of lids." 5

As an eye, ear, nose, and throat specialist, Cox also treated several patients with basal skull fractures, all of whom died. He repaired any face, head, or neck lacerations. "In two, the face had been cloven down, slanting from the bridge of the nose, as if with a hatchet," remembered Cox, "going thro' the nasal cavities and antra and the whole flap hanging forward." In both cases, Cox replaced the flap and inserted tubes through the nostrils. The two flap patients survived. ${ }^{5}$

By the fifth day, Cox had an organized ward. He had treated all but a few dozen patients, many of whom were late to present. "At this time a confrere from Montreal arrived in the city, Dr. Tooke," recalled Cox, "and I was glad to hand the remnants to him." $"$

Tooke arrived to a ward of 120 patients, all requiring major eye surgery. ${ }^{4} \mathrm{He}$ was immediately taken aback by the severity of the cases. Several patients with sutured lacerations presented with necrotic wounds. "Practically every face wound was septic," recollected Tooke, "nay more, each was welling out with a copious purulent discharge while other wounds appeared almost to be gangrenous." 4

Tooke quickly organized a surgical team consisting of a general practitioner, a senior medical student, and an Army Service Corps sergeant. He instructed Sergeant Wallace to take note of each patient's name, case, and treatment, and published a record of his experience in the April 1918 edition of the Canadian Medical Association Journal, with a list of 48 treated patients. ${ }^{4}$

Tooke described several of his cases in further detail. Enucleations were complicated by indurated, necrosing conjunctiva. Tooke practised the Lister operation with some enucleations, a procedure designed to prevent the spread of infection behind the orbit by leaving a "small curtain" of sclera about the optic nerve. However, he admitted to better results with simple enucleations. ${ }^{4}$

Cases of retained glass caused significant inflammation and a bloody serous discharge. Tooke removed glass and other foreign bodies, freed incarcerated iris, excised prolapsed iris and ciliary bodies, and performed iridectomies. Severe wounds involving both perforations of the cornea/sclera and prolapsed uveal tract or vitreous were enucleated. Completely destroyed eyes were enucleated.

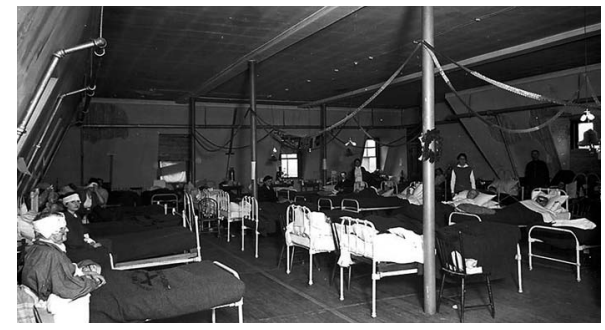

Fig. 6-City of Toronto archival photograph of a temporary hospital in Halifax set up by the Medical Relief Committee for patients of the 1917 Halifax Explosion. 
Cornea perforations and traumatic cataracts were treated conservatively with atropine, argyrols as antiseptic, and dressings. Lacerated lids were sutured and dressed. ${ }^{4}$

Tooke attempted to preserve the eyes in most cases, but several patients requiring enucleation presented with injuries classified as "completely collapsed," "completely destroyed," or "organs cannot be distinguished." One female patient, M.A., had "both eyes and appurtenances torn to shreds" with "multiple glass wounds of the face and neck." Tooke performed 16 enucleations in total and 2 double enucleations, with an enucleation rate of $33 \% .{ }^{4}$ The overall enucleation rate for all 12 oculists was $48 \%{ }^{8}$

On December 18, 20 patients remained on the Camp Hill Military Hospital eye ward, most unable to return home because of the destruction of their houses. Tooke returned to Montreal. ${ }^{4}$

Sir Frederick Fraser, superintendent of the Halifax School for the Blind, was instrumental in ensuring those suffering eye injuries received proper medical care, followup treatment, dressing changes, and financial compensation. ${ }^{7,10} \mathrm{He}$ helped organize the Blind Relief Fund through the Halifax Relief Committee. Fraser also organized eye clinics and had medical staff perform house calls. ${ }^{7,10}$

In January 1918, Fraser published an advertisement in the local newspapers requesting information from patients with eye injuries. ${ }^{9}$ More than 100 letters were received in which patients described the nature of their injuries and their treatment (Fig. 3). ${ }^{7}$

Patients were compensated for medical bills, including the cost of artificial eyes and eyeglasses. By June 1918, the Medical Relief Committee had supplied a total of 145 artificial eyes and an unspecified number of spectacles and eyeglasses. ${ }^{8,10}$ Forty persons were reported as totally blind, including 8 children. Forty-eight children suffered eye injuries (Fig. 7). The Halifax Relief Commission sponsored these children to attend the Halifax School for the Blind.7,10

The commission also offered financial compensation to those injured in the explosion. They were offered either a lump sum or a monthly pension. ${ }^{18}$ The MassachusettsHalifax Relief Committee provided $\$ 25000$ for blind relief to provide special equipment for blind housewives, including bread mixers, washing machines, and sewing machines. ${ }^{12}$ The total medical cost of the explosion was $\$ 4$ million, equivalent to $\$ 55$ million today. ${ }^{7,10}$

\section{Conclusions}

Cox and Tooke provide incredible details about the nature and management of the eye injuries treated in the days following the Halifax Explosion. "It was as if the ball had been laid open," recollected Cox of an eye injury, "and then stuffed with pieces of glass - or sometimes crockery, brick, splinters. And on palpation they would clink."

Both oculists mentioned the feared complications of tetanus, erysipelas, and other postoperative infections.
Neither surgeon reported these unwanted consequences in their patients. ${ }^{4,5}$

Sympathetic ophthalmia, a bilateral granulomatous panuveitis secondary to a penetrating injury, was also a feared complication. In 1917, it was suspected to occur secondary to a toxin from pathogenic bacteria. ${ }^{19}$ Several patients reported an enucleation of the injured eye to prevent sympathetic ophthalmia. "My injured eye had to be removed to save the sight of the other one," wrote one patient in a letter to Sir Frederick Fraser. ${ }^{7}$

The discrepancy between Tooke's enucleation rate of $33 \%$ and the overall enucleation rate of $48 \%$ could be due to Tooke's more conservative approach. "Most of the enucleating at Camp Hill had been performed by my predecessors, Dr. Cox and Dr. McLennan," wrote Tooke, "although a few choice specimens-probably a dozencomplicated cases were left over for my particular edification." " However, Tooke arrived in Halifax on the morning of the fifth day after the explosion and many of the more severe injuries (likely requiring more aggressive surgical intervention) had already been treated by local oculists.

Although Cox and Tooke both mention their encounter in the written accounts, no correspondence between the 2 oculists was found. Cox continued his practice in New Glasgow and maintained an interest in geology and conchology. ${ }^{20,21} \mathrm{He}$ described a new species of oyster, Oystra coxae, named after its discoverer. ${ }^{20}$ Tooke became the chairman of the Department of Ophthalmology at McGill University with an interest in ocular pathology. ${ }^{22,23}$ Tooke published widely and served as president of the Montreal, Canadian, and American Ophthalmological Societies. Tooke is considered a founder of modern Canadian ophthalmology. ${ }^{24}$ Both Cox and Tooke died at the age of $82 .{ }^{20,22}$

In their personal accounts, Cox and Tooke recognize the unique nature of their surgical experience afforded by the explosion. "I would acknowledge with deep gratitude the privilege and the unusual opportunity accorded me, probably that of a lifetime, of helping suffering humanity,"

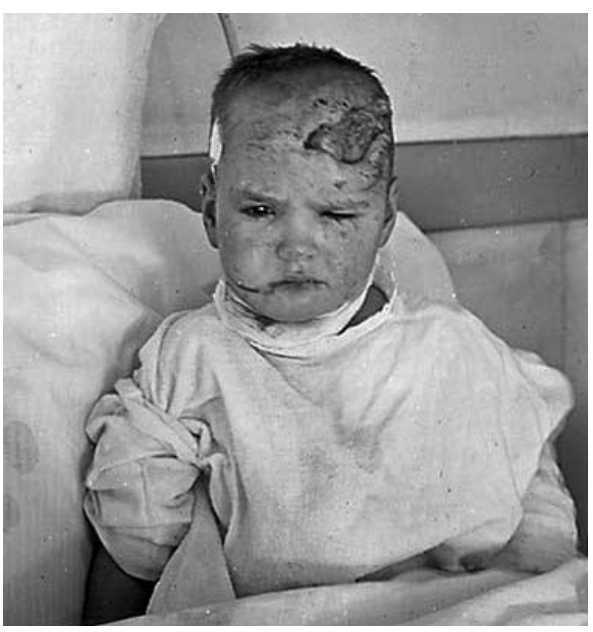

Fig. 7-One of 48 children who suffered eye injuries in the 1917 Halifax Explosion. 
wrote Tooke. " "I had realised," wrote Cox, "that here was the kind of thing one dreams about sometimes - enough cases to keep one going steadily for days and days ahead." 5

\section{REFERENCES}

1. MacMechan Fond. Medical Relief Committee of the Halifax Disaster. PANS MG 1 vol. 2124:1-20.

2. Ruffman A, Howell CD, eds. Ground zero: a reassessment of the 1917 explosion in Halifax harbour. Halifax: Nimbus Publishing Ltd and Gorsebrook Research Institute, St. Mary's University; 1994:276-7.

3. Halifax stunned by blast; thought Germans had attacked from sea and air simultaneously. Boston Post. Dec. 7, 1917.

4. Tooke FT. An experience through the Halifax disaster. CMAJ 1918;8:308-20.

5. Cox G. PANS MG 1 vol. 2606 no. 169.

6. McCall S. Telegram: Governor of Massachusetts. PANS MG 36 series $\mathrm{C}$ vol. 113.

7. Halifax Relief Commission. PANS MG 36 series C vol. 120.

8. Medical Relief Committee. PANS RG 14 series S vol. 17 no. 3.

9. Information wanted. Halifax Evening Mail. January 5, 1918.

10. Harris DF. Fraser Harris Report: the medical relief work of the Halifax disaster. PANS MG 36 series C vol. 119.

11. Murray TJ. Medical aspects of the disaster: the missing report of Dr. David Fraser Harris. In: Ruffman A, Howell CD, eds. Ground zero: a reassessment of the 1917 explosion in Halifax harbour. Halifax: Nimbus Publishing Ltd and Gorsebrook Research Institute, St. Mary's University; 1994.
12. Massachusetts-Halifax Relief Committee. PANS MG 36 series C vol. 84

13. Kitz JF. Shattered city: the Halifax Explosion and the road to recovery. Halifax: Nimbus Publishing Ltd; 1989:173-95.

14. MacDonald LM. Curse of the narrows: the Halifax Explosion of 1917. Toronto: HarperCollins Publishers; 2004.

15. McAlister CN, Murray TJ, Lakosha H, Maxner CE. The Halifax disaster (1917): eye injuries and their care. $\mathrm{Br} J$ Ophthalmol 2007;91(6):832-5.

16. Halifax Foundation. Halifax Explosion remembrance book. Maritime Museum of the Atlantic. 2002. Available at: http://museum.gov.ns.ca/mma/AtoZ/expbook.html.

17. Canadian Red Cross Society. PANS MG 36 series C vol. 120 no. 1a.

18. CNIB Halifax Relief Commission eye cases. PANS MG 36 series C vol. 28.

19. May CH. Disease of the eye. New York: William Wood and Company; 1914.

20. Obituaries. Dr. George Hastings Cox. CMAJ 1953;83:300.

21. Dr. George H. Cox. New Glasgow Eastern Chronicle. January 8, 1953.

22. Nicholls JVV. Frederick Thomas Tooke, M.D. Trans Am Ophthalmol Soc 1956;54:23-5.

23. Obituary. Frederick Thomas Tooke. Br J Ophthalmol 1955;39(10):640.

24. Obituaries. Dr. Walter Walker Wright. CMAJ 1968;98:1157-8.

Key words: Halifax Explosion, Halifax Disaster, eye injuries 